\title{
EVALUATING LECTURER'S ACADEMIC PERFORMANCE OF COKROAMINOTO UNIVERSITY OF YOGYAKARTA
}

\author{
Oleh : Didik Rinan Sumekto
}

\begin{abstract}
Abstrak
Penelitian ini bertujuan mengungkapkan persepsi kinerja dosen ditinjau dari (1) penguasaan materi kuliah, (2) manajemen kelas, (3) komunikasi dosen dan mahasiswa dalam proses belajar-mengajar, dan (4) kemampuan mengevaluasi proses dan hasil pembelajaran.

Populasi penelitian ini adalah seluruh mahasiswa di Universitas Cokroaminoto Yogyakarta yang berjumlah 1.442 orang dan sampel penelitian ini sebanyak 187 orang yang ditentukan dengan menggunakan rumus Cohen. Pengambilan sampel menggunakan teknik proportional stratified random sampling. Pengumpulan data dilakukan dengan menggunakan angket dengan 5 skala Likert Summited Rating Scale yang digunakan untuk mendapatkan data kinerja dosen, penguasaan materi kuliah, manajemen kelas, komunikasi dosen dan mahasiswa dalam proses belajar-mengajar, dan kemampuan mengevaluasi proses dan hasil pembelajaran. Data yang diperoleh dianalisis dengan statistik deskriptif, analisis korelasi sederhana dan analisis regresi ganda dengan taraf signifikansi 0,05.

Persepsi mahasiswa berdasarkan penguasaan materi kuliah, manajemen kelas, komunikasi dosen dan mahasiswa dalam proses belajar-mengajar, dan kemampuan mengevaluasi proses dan hasil pembelajaran secara bersama-sama berpengaruh positif dan signifikan terhadap kinerja dosen $\left(F=17,676 ; R^{2}=0,280 ; p<\right.$ 0,000). Kontribusi keefektifannya sebesar 28,0\%, sehingga 72,0\% masih dipengaruhi oleh variabel di luar penelitian ini. Hasil analisis linier menunjukkan pengaruh positif dan signifikan penguasaan materi kuliah terhadap kinerja dosen secara parsial $(t=2,800 ; p=0,006)$. Manajemen kelas menunjukkan pengaruh positif dan signifikan terhadap kinerja dosen secara parsial $(t=3,220 ; p=0,002)$. Komunikasi dosen dan mahasiswa dalam proses belajar-mengajar menunjukkan pengaruh positif dan signifikan terhadap kinerja dosen secara parsial $(t=3,609 ; p=0,000)$. Kemampuan mengevaluasi proses dan hasil pembelajaran menunjukkan pengaruh positif dan signifikan terhadap kinerja dosen secara parsial $(t=2,745 ; p=0,007)$. Hasil analisis persamaan regresi ganda yang diperoleh dengan cara bertahap (stepwise) adalah $Y=12,490+0,223 X 1+0,186 X 2+$ $0,236 \times 3+0,136 \times 4$.
\end{abstract}

Kata Kunci : Kinerja dosen, penguasaan materi kuliah, manajemen kelas, komunikasi, evaluasi pembelajaran.

Didik Rinan Sumekto : adalah Dosen Progam Pendidikan Bahasa Inggris, UNWIDHA Klaten 


\section{INTRODUCTION}

The education domain shall realize that every education process is intended to supply and create as much as potentially well-educated experts in order to establish the nation roles. Education means to increase the human's self-esteem and support to the citizen's development in order to live free, think rationale and be fully responsible (Moh Amien, 1995: 9). Therefore, each educational institution shall be responsible to the education goals referring to its levels and objectives that are being developed. The education goals that have been determined and developed by each educational institution, then implemented to every lecture.

Unfortunately, the current issues that appear in the leading sector are about the higher education lecturers with the high professionalism and qualification needed. Ahmad Rohani (2004: 111-158) points out that some stumbling factors still lead to the teaching and learning atmosphere, such as the lecturer's absoluteness and less democratic leadership in delivering the instruction materials which may contribute the students' fear and apathies, the monotonous instruction in the classroom which lead to the students' reluctance and frustration; (3) the lecturer's personality who are not fair enough, objective, adaptive, and humble. This impact will bring upset emotion in the students' teaching and learning; (4) the lecturer's knowledge is limited, either theoretical or practical experiences which will not support to the outputs and a good impression to the students; and (5) the lecturer's understanding to the students' condition is still ignorant as well. The lecturer's position to understand some students' behaviors and backgrounds may be neglected as it is perceived that the lecturer feels ignorant, has plenty of teaching hours, and other activities outside the campus, therefore some lecturers come to the class for teaching merely.

Moh Amin (1995: 1-2) explores that there are still many lecturers acting theirself as the transmitter of knowledge only, not the educators. The lecturers regard this phenomena as the conscious and or unconscious condition in which the students stand for the learning object only and they do not have enough chances to express their potential intellectual and personality to be self-actualized persons toward the fully functioning persons. This learning paradigm at the higher education institutions shall focus to the students centered learning that will support to the competency-based learning and neglect the lecturer centered instructional model. The lecturer centered instructional model will lead to the passive learning atmosphere where the teaching and learning process focuses to the single way only, thus the students do not motivate to reveal their ideas (KompasYogyakarta edition, 2005: G, downloaded on October $\left.4^{\text {th }}, 2005\right)$. The orientation of coaching the students from the behind role is not sufficient and effective enough. One important thing to do is that the lecturer shall directly raise and stimulate the students' interest as the active and creative learners, and be a good role model in achieving a substantial education output.

The ideal academic society relationship coaching conceptually and operationally needs to reflect the following aspects: (1) a conducive circumstance created among the academic society; (2) a fit and proper academic norms due to its circumstantial norms; and (3) every academic society member-students, lecturers, and staff shall be able to understand, perceive, and implement their own roles with the integrated and comprehensive ways (Moh Amien, 1995: 3-4). To provide the substantial education outputs, a higher education institution or 
university needs to be supported by highly motivated and qualified human resources, financial resources, and modern information technology providers. The higher education institution's increase is considered as one of the mostly important indicators to prove the nation development, as the university is regarded as the mostly human resources producer (Kompas Yogyakarta edition, 2005: G, downloaded on October $\left.15^{\text {th }}, 2005\right)$.

It is undeniable that several problems are still faced by higher education institutions, either in relating with the lecturer's qualification or good university governance. These problems refer to the condition at Cokroaminoto university of Yogyakarta, as indicated as follows: (1) there is still lecturer's intention to reach any managerial positions rather than functional positions. This condition is caused by the unfair career path, limited facilities received, and functional position authorities which lead the lecturer to be more desirable to reach the managerial positions. So far, ironically, there is no standard operation procedure of the performance assessment to any position level. This condition has neglected to the important professionalism development planning, as regarded to lead the competitive and comparative benefits only; (2) lack of remuneration and or incentive given to the lecturers. This condition triggers to the mostly lecturers who tend to earn the other income sources outside their institution and it regularly disturbs the major assignments the lecturers have so far; (3) there is an institution dysfunction symptom that impacts to the staff dysfunction position to meet any additional positions decided internally. This condition will off course lead to the ineffectiveness of lecturer's capacity; (4) there are some complaints coming from the students regarding with the low performance on the lecturer's subject mastery during the spam of teaching and learning process; (5) some lecturers are still lack of providing a good classroom management which impacts to the ineffective teaching and learning process; (6) most students still find difficulties to communicate efficiently and effectively with their lecturers in touching with the teaching and learning process inside and outside the academic affairs; and (7) it is needed any intensive analysis toward the lecturer's capability of evaluating the instruction output and process which is still regarded as the crucial problems to solve.

Indeed, there are some phenomena concerning with the unsatisfied lecturer's academic performance, which make these problems will be very crucial to the teaching and learning issues if a lecturer truly takes care and makes his or her current updates when delivering any subject matters. The lecturer shall be in charge with all efforts, as his or her students directly face with him or her in the teaching and learning process. Meanwhile, the students are expected to give some information and constructive criticism objectively every time in the teaching and learning process due to their own instruction perception. Then, it is expected that the lecturer is able to increase his or her teaching performance and do some improvement of teaching and learning competencies.

In general, the performance appraisal refers to some evidences of truth that every lecturer individually meets at least the performance standard instructed. It is also a way of assisting every individual runs his or her performance (Anthony, et al, 2002: 351). Genoveva and Vita (2005: 4) as well as emphasize that the lecturer's performance appraisal may be notified precisely in accordance with what is going on right now and what targets shall be fulfilled. The transparent and accountable assessment system will motivate the lecturer to achieve a desirable 
performance. Through the performance appraisal some plans and strategy issues can be well-arranged to decide that the important steps in relating with the career paths are possible to achieve.

\section{RESEARCH OBJECTIVE}

This major research objectives are due to into five following aspects:

1. To identify and analyze the positive and significant influence of subject mastery toward the lecturer's performance.

2. To identify and analyze the positive and significant influence of classroom management toward the lecturer's performance.

3. To identify and analyze the positive and significant influence of communication in teaching and learning process involving both students and lecturer toward the lecturer's performance.

4. To identify and analyze the positive and significant influence of evaluating capability on the instructional output and process toward lecturer's performance.

5. Collectively, this research objective is to identify and analyze the subject mastery, classroom management, communication in teaching and learning process involving both students and lecturer, and evaluation capability on the instructional output and process which influence toward the lecturer's performance significantly and positively.

\section{RESEARCH METHOD}

The applied research method here is a descriptive quantitative research. This method is meant to explore and analyze deeply some matters concerning with the research focus of evaluating lecturer's academic performance at Cokroaminoto University of Yogyakarta. This research method approach attempts to describe the research problems holistically and be comprehension in data collection, input, analysis, and discussion through the wholly research activities. These research findings are meant to identify and analyze the subject mastery, classroom management, communication in teaching and learning process, and evaluation capability on the instructional output and process towards the lecturer's performance at Cokroaminoto University of Yogyakarta.

The research population is all students at Cokroaminoto University of Yogyakarta. The students' determination as the research respondents are based on their accessibility reached and their relationship homogeneity regarding with the age, sex, education background, etc. Cokroaminoto University of Yogyakarta students are totaling 1,442 From the total active students in 2006 can be classified into 123 students of Teacher Training and Education Faculty, 378 students of Law Faculty, 471 students of Economic Faculty, 216 students of Engineering Faculty, and 254 students of Islamic Religion Faculty. The sample size determination uses Cohen formulation (1977: 439), in which the assumption of this research will have a normal contribution by firmly considering the significance value size (a), power (1b), variable number $(U)$, and effect size $\left(\begin{array}{l}12 \\ 1\end{array}\right)$. 


\section{RESEARCH FINDINGS AND DISCUSSION}

\section{The summary of research data description}

The scoring of research findings is definitely done to each variable, then it is analyzed through the statistical package for social science (SPSS) program to determine the instrument contribution size to variables or factors based on the factors loading in each supporting instrument and apply for the descriptive statistics analysis technique, simple correlation analysis, and the two-tailed regression analysis with the significance level of 0,05 . Herewith, the summary of data description is revealed below.

\section{Lecturer's performance}

The data analysis output of lecturer's performance variable can be viewed from the table 1 below which indicates that there are $1,1 \%$ or 2 respondents stating the lecturer's performance is very good; $86,1 \%$ or 161 respondents stating the lecturer's performance is good; $12,8 \%$ or 24 respondents stating the lecturer's performance is average; and there is no respondent stating that the lecturer's performance is below average. The interval score to the variable of lecturer's performance is between 33 to 80 . Based on the research findings, it is obtained that the lowest score is 33 and the highest score is 80 , and categorized as good.

Table 1.

Lecturer's performance score distribution (Y)

\begin{tabular}{|c|c|c|c|c|c|c|}
\hline & Category & Interval & Frequency & Percent & Valid Percent & Cumulative Percent \\
\hline \multirow[t]{4}{*}{ Valid } & 2 Average & $(>33-48)$ & 24 & 12.8 & 12.8 & 12.8 \\
\hline & 3 Good & $(>49-64)$ & 161 & 86.1 & 86.1 & 98.9 \\
\hline & 4 Very Good & $(>65-80)$ & 2 & 1.1 & 1.1 & 100.0 \\
\hline & Total & & 187 & 100.0 & 100.0 & \\
\hline
\end{tabular}

\section{Subject Mastery}

The data analysis output of subject mastery variable can be viewed from the table 2 below which indicates that there are $4,3 \%$ or 8 respondents stating the lecturer's subject mastery is very good; $93,0 \%$ or 174 respondents stating the lecturer's subject mastery is good; $2,7 \%$ or 5 respondents stating the lecturer's subject mastery is average; and there is no respondent stating that the lecturer's subject mastery is below average. The interval score to the variable of subject mastery is between 33 to 80 . Based on the research findings, it is obtained that the lowest score is 33 and the highest score is 80 , and categorized as good. 
Table 2.

Subject mastery score distribution (X1)

\begin{tabular}{|c|c|c|c|c|c|c|}
\hline & Category & Interval & Frequency & Percent & Valid Percent & Cumulative Percent \\
\hline \multirow[t]{4}{*}{ Valid } & 2 Average & $(>33-48)$ & 5 & 2.7 & 2.7 & 2.7 \\
\hline & 3 Good & $(>49-64)$ & 174 & 93.0 & 93.0 & 95.7 \\
\hline & 4 Very Good & $(>65-80)$ & 8 & 4.3 & 4.3 & 100.0 \\
\hline & Total & & 187 & 100.0 & 100.0 & \\
\hline
\end{tabular}

\section{Classroom Management}

The data analysis output of classroom management variable can be viewed from the table 3 below which indicates that there are $8,0 \%$ or 15 respondents stating the lecturer's classroom management is very good; $79,7 \%$ or 149 respondents stating the lecturer's classroom management is good; $12,3 \%$ or 23 respondents stating the lecturer's classroom management is average; and there is no respondent stating that the lecturer's subject mastery is below average. The interval score to the variable of subject mastery is between 33 to 80 . Based on the research findings, it is obtained that the lowest score is 33 and the highest score is 80 , and categorized as good.

Table 3.

Classroom management score distribution (X2)

\begin{tabular}{llccccc}
\hline \hline & Category & Interval & Frequency & Percent & Valid Percent & Cumulative Percent \\
\hline \multirow{2}{*}{ Valid } & 2 Average & $(>33-48)$ & 23 & 12.3 & 12.3 & 12.3 \\
& 3 Good & $(>49-64)$ & 149 & 79.7 & 79.7 & 92.0 \\
& 4 Very Good & $(>65-80)$ & 15 & 8.0 & 8.0 & 100.0 \\
Total & & $\mathbf{1 8 7}$ & $\mathbf{1 0 0 . 0}$ & $\mathbf{1 0 0 . 0}$ & \\
\hline \hline
\end{tabular}

\section{Communication in teaching and learning process}

The data analysis output of communication in teaching and learning process variable can be viewed from the table 4 below which indicates that there are $4,3 \%$ or 8 respondents stating the lecturer's communication in teaching and learning process is very good; $86,6 \%$ or 162 respondents stating the lecturer's communication in teaching and learning process is good; $8,6 \%$ of the lecturer's communication in teaching and learning process is average; and only $0,5 \%$ or 1 respondent stating that the lecturer's communication in teaching and learning process is below average. The interval score to the variable of communication in teaching and learning process is between 15 to 75 . Based on the research findings, it is obtained that the lowest score is 15 and the highest score is 75 , and categorized as good. 
Table 4.

Communication in teaching and learning score distribution (X3)

\begin{tabular}{|c|c|c|c|c|c|c|}
\hline & Category & Interval & Frequency & Percent & Valid Percent & Cumulative Percen \\
\hline \multirow[t]{5}{*}{ Valid } & 1 Below Avera & $(15-30)$ & 1 & .5 & .5 & .5 \\
\hline & 2 Averag & $(>31-45)$ & 16 & 8.6 & 8.6 & 9.1 \\
\hline & 3 Good & $(>46-60)$ & 162 & 86.6 & 86.6 & 95.7 \\
\hline & 4 Very Good & $(>61-75)$ & 8 & 4.3 & 4.3 & 100.0 \\
\hline & Total & & 187 & 100.0 & 100.0 & \\
\hline
\end{tabular}

The capability of evaluating the instructional output and process

The data analysis output of communication in teaching and learning process variable can be viewed from the table 5 below which indicates that there are $19,3 \%$ or 36 respondents stating the lecturer's capability of evaluating the instructional output and process is very good; $66,8 \%$ or 125 respondents stating the lecturer's capability of evaluating the instructional output and process is good; 13,9\% or 26 respondents stating the lecturer's capability of evaluating the instructional output and process is average; and there is no respondent stating that the lecturer's capability of evaluating the instructional output and process is below average. The interval score to the variable of capability of evaluating the instructional output and process is between 31 to 75. Based on the research findings, it is obtained that the lowest score is 30 and the highest score is 75 , and categorized as good.

Table 5.

Capability of evaluating the instructional output and process (X4)

\begin{tabular}{llccccc}
\hline \hline & Category & Interval & Frequency & Percent & Valid Percent & Cumulative Percent \\
\hline \multirow{2}{*}{ Valid } & 2 Average & $(>31-45)$ & 26 & 13.9 & 13.9 & 13.9 \\
& 3 Good & $(>46-60)$ & 125 & 66.8 & 66.8 & 80.7 \\
4 Very Good & $(>61-75)$ & 36 & 19.3 & 19.3 & 100.0 \\
Total & & $\mathbf{1 8 7}$ & $\mathbf{1 0 0 . 0}$ & $\mathbf{1 0 0 . 0}$ & \\
\hline \hline
\end{tabular}




\section{DISCUSSION ON DATA ANALYSIS}

\section{Descriptive analysis}

The descriptive statistics analysis results show that all variables of subject mastery (X1), classroom management (X2), communication in teaching and learning process (X3), and capability of evaluating the instructional output and process (X4) or even lecturer's performance $(\mathrm{Y})$ are categorized as good with the respondent's average response of 4 (four) in the Likert Scale. These results can be precisely described as follows:

\section{Lecturer's performance}

The data analysis output obtained concerning with the lecturer's performance shows that, where $\mathrm{R}$ $=0,529 ; \mathrm{F}=17,676$; and $\mathrm{p}=0,000$ with the regression line equality, $\mathrm{Y}=12,490+0,223 \mathrm{X} 1+0,186 \mathrm{X} 2+$ $0,237 \mathrm{X} 3+0,136 \mathrm{X} 4$. Based on the indicators evaluated in this research, it requires that the lecturer must hold and prove any academic competency and wide and good learning methodology, be able to communicate mutually with the students in academic and social domain, to be councelor and to guide the students in achieving the better learning outputs, and to accommodate the teaching and learning process into the enjoyful and meaningful process. Every independent variable in this research each contributes $22,3 \%$ toward subject mastery (X1); 18,6\% toward classroom management (X2);23,6\% toward communication in teaching and learning process (X3); and $13,6 \%$ toward capability of evaluating the instructional output and process (X4). The contribution of four independent variables is $28,0 \%$.
Table 6.

Two-tailed regression equivalence analysis Model Summary (b)

\begin{tabular}{llllll}
\hline \hline Model & $R$ & R Square & Adjusted & Std. Enror of \\
& & & R Square & the Estinate \\
\hline 1 & $.529^{a}$ & .280 & .264 & 4.787 & 2.000 \\
\hline \hline
\end{tabular}

a. Predictors: (Constant), subject mastery (X1), classroom management (X2), Communication in teaching and learning process (X3), capability of evaluating the instructional output and process (X4)

b. Dependent Variable: Lecturer's performance (Y)

\begin{tabular}{|c|c|c|c|c|c|c|}
\hline \multicolumn{7}{|c|}{ ANOVA (b) } \\
\hline & & Sum of & & Mean & & \\
\hline \multicolumn{2}{|c|}{ Model } & Squares & d & Square & $\mathrm{F}$ & Sig. \\
\hline \multirow[t]{3}{*}{1} & Regression & 1620.427 & 4 & 405.107 & 17.676 & $.000^{\mathrm{a}}$ \\
\hline & Residual & 4171.252 & 182 & 22.919 & & \\
\hline & Total & 5791.679 & 186 & & & \\
\hline
\end{tabular}

a. Predictors: (Constant), subject mastery (X1), classroom management (X2), Communication in teaching and learning process (X3), capability of evaluating the instructional output and process (X4)

b. Dependent Variable: Lecturer's performance (Y) 
Coefficients(a)

\begin{tabular}{|c|c|c|c|c|c|c|}
\hline \multicolumn{2}{|c|}{ Model } & \multirow{2}{*}{\multicolumn{2}{|c|}{$\begin{array}{r}\begin{array}{r}\text { Unstandardized } \\
\text { Coefficients }\end{array} \\
\text { Std. Error } \\
\end{array}$}} & \multirow{2}{*}{$\begin{array}{r}\begin{array}{r}\text { Standardized } \\
\text { Coefficients }\end{array} \\
\text { Beta }\end{array}$} & \multirow[b]{2}{*}{$\mathrm{t}$} & \multirow[b]{2}{*}{ Sig. } \\
\hline & & & & & & \\
\hline \multirow[t]{6}{*}{1} & (Constant) & 12.490 & 5.216 & & 2.395 & .018 \\
\hline & Subject mastery (X1) & .223 & .080 & .191 & 2.800 & .006 \\
\hline & $\begin{array}{l}\text { Classroom } \\
\text { management (X2) }\end{array}$ & .186 & .058 & .211 & 3.220 & .002 \\
\hline & $\begin{array}{l}\text { Communication in } \\
\text { teaching and learning } \\
\text { process (X3) }\end{array}$ & .236 & .065 & .242 & 3.609 & .000 \\
\hline & $\begin{array}{l}\text { Capability of } \\
\text { evaluating the } \\
\text { instructional output }\end{array}$ & & & & & \\
\hline & and process (X4) & .136 & .049 & .180 & 2.745 & .007 \\
\hline
\end{tabular}

a. Dependent Variable: Lecturer's performance (Y)

\section{Subject mastery}

The significance level of subject mastery variable lies on the third level in this research with the data analysis output obtained, where $t=2,800 ; p$ $=0,006$ and the regression line equality is $\mathrm{Y}=12,490$ $+0,223 \times 1$. Based on the indicators evaluated in this research, it requires that the lecturer must be able to choose and use the appropriate teaching materials, how to specify and explain the materials comprehensively, to instruct the teaching and learning materials due to its education level, and to specify the learning objectives through the lesson plan.

\section{Classroom management}

The significance level of class management variable lies on the second level in this research with the data analysis output obtained, where $t=3,220 ; p$ $=0,002$ and the regression line equality is $Y=12,490$ $+0,186 \times 2$. Based on the indicators evaluated in this research, it requires that the lecturer must be able to create a condusive learning atmosphere either physical or socio-emotional aspects, to understand every different character and condition among the students, to commit and allocate the effective time in instructing the materials, and to do the corrective action. 


\section{Communication in teaching and learning process}

The significance level of communication in teaching and learning process variable lies on the first level in this research with the data analysis output obtained, where $\mathrm{t}=3,609 ; \mathrm{p}=0,000$ and the regression line equality is $\mathrm{Y}=12,490+0,237 \mathrm{X} 3$. Based on the indicators evaluated in this research, it requires that the lecturer must be able to understand and put the students as the subject of learners, to realize the students' characterictics, to allocate the meeting frequencies with the students for academic and nonacademic consultancies to meet and coach physically, and to approach the students with the humanistic ways, either pedagogical-phycological or socialconstructive contact.

\section{Capability of evaluating the instructional output and process}

The significance level of capability of evaluating the instructional output and process variable lies on the fourth level in this research with the data analysis output obtained, where $t=2,745 ; p$ $=0,007$ and the regression line equality is $\mathrm{Y}=12,490$ $+0,136 \mathrm{X} 4$. Based on the indicators evaluated in this research, it requires that the lecturer must be able to do the evaluation objectively in accordance with the learning materials taught, to evaluate the teaching and learning activities objectively, proportionally and simultanously and the instruction improvement, and to use the evaluation outputs for coaching activities of the sustainable teaching and learning process.

\section{CONCLUSION}

From the descriptive analysis outputs and discussion of the research findings, this conclusion breakdowns into following:

1. The lecturer's performance of subject mastery (X1) is good, it contributes 93\%; classroom management (X1) is good, it contributes $79,7 \%$; communication in teaching and learning process (X3) is good, it contributes $86,6 \%$; and capability of evaluating the instructional output and process (X4) is good as well, it contributes $66,8 \%$ from the research variables.

2. There is a positive and significant influence of subject mastery (X1) toward the lecturer's performance $(Y)$, where $t=2,800$ and $p=0,006$;

3. There is a positive and significant influence of classroom management (X2) toward the lecturer's performance $(\mathrm{Y})$, where $\mathrm{t}=3,220$ and $\mathrm{p}=0,002$;

4. There is a positive and significant influence of communication in teaching and learning process (X3) toward the lecturer's performance (Y), where $\mathrm{t}=3,609$ and $\mathrm{p}=0,000$;

5. There is a positive and significant influence of capability of evaluating the instructional output and process (X4) toward the lecturer's performance $(Y)$, where $t=2,745$ and $p=0,007$; and

6. There is collectively a positive and significant influence of subject mastery (X1), classroom management $(\mathrm{X} 2)$, communication in teaching and learning process (X3), and capability of evaluating the instructional output and process (X4) toward the lecturer's performance (Y), where $\mathrm{R}=0,529 ; \mathrm{F}=17.676$; and $\mathrm{p}=0.000$. 


\section{REFERENCE}

Ahmad Rohani. (2004). Pengelolaan pengajaran (edisi revisi). Jakarta: PT. Rineka Cipta.

Anthony, P.W., Kacmar, M.K., Perrewé, L.P. (2002). Human resource management a strategic approach (4th ed.). Ohio: South-Western.

Cohen, J. (1977). Statistical power analysis for the behavioral sciences (Rev. ed.). New York: Academic Press.

Genoveva \& Vita, E.M. (2004). Menyusun sistem penilaian kinerja dosen yang mendukung tri dharma perguruan tinggi. Diambil pada tanggal 23 September 2005 dari http:// www.depdiknas.go.id/Jurnal/51/040507-edgenoveva \& elizabeth menyusun sistem penilaian.pdf.
Moh Amien. (1995). Proses belajar-mengajar di perguruan tinggi: Bahan penataran untuk latihan pra jabatan golongan III IKIP Yogyakarta (15 Pebruari-23 Maret 1995). Yogyakarta: Departemen Pendidikan Dan Kebudayaan.

Pembelajaran harus berpusat pada mahasiswa. (4 Oktober 2005). Kompas-edisi Yogyakarta, p. G.

Pemerintah perlu beri dukungan pendanaan. (15 Oktober 2005). Kompas-edisi Yogyakarta, p. G. 